\title{
Cybercrime in Online Dating Site: Pornography Business in the Virtual World
}

\author{
Rizki Briandana ${ }^{1}$, Irmawati Oktavianingtyas ${ }^{2}$, Rustono Farady Marta ${ }^{3}$ \\ Universitas Mercu Buana, Jln. Meruya Selatan No.1, West Jakarta, 11650, Jakarta, Indonesia ${ }^{1,2}$ \\ Universitas Bunda Mulia, Jln. Lodan Raya No. 2, North Jakarta, 14430, Jakarta, Indonesia ${ }^{3}$ \\ rizki.briandana@mercubuana.ac.id ${ }^{1}$,oktavianingtyas.irmawati@gmail.com²rmarta@bundamulia.ac.id³
}

\begin{abstract}
Online dating sites have been a common tool for individuals to find and meet new companions and potential mates. Although it has the potential to bring great happiness into their lives, many individuals have been slow to recognize the cyber risk connected to these dating sites such as cybercrime and cyber pornography. The researcher has performed an analysis on an online dating site to know how cybercrime and pornography developed in the virtual world. The researcher used the case study method. Interviews were conducted with five key informants who had been an active member of the dating site to provide information. The result shows that there are three kinds of cybercrime activities which involve pornography content at the dating site. The first is hacking; the second is sextortion, and the third one is online prostitution. The result also shows a cybercrime activity that does not involve pornography content called doxxing.
\end{abstract}

Keywords: Case Study, Cybercrime, Pornography, Online Dating.

\section{Introduction}

Every day, people spend a lot of time browsing the internet, and even more time on their mobile phone. Technology and available applications of mobile phone are evolving quickly all around the world [1]. There are five billion devices (mobile phone/computer, etc) connected and remotely accessed from the internet on 2012 and the number of internet-connected devices is exceed 15 billion by 2015 and to soar to 50 billion devices by 2020 [2]. While Technology continues to develop quickly, many individuals have been slow to recognize the cyber risk connected to this technology [3].

Cyber risk itself means the risk of financial loss, disruption or damage to the reputation of an organization or individual caused by the failure of its information technology system [4]. One of the cyber risks we are facing right now is the existence of cybercrime [5]. Cybercriminals can come from anywhere and they could be closer than we think. Even in a place to look for happiness like online dating websites, people are exposed to the danger of cybercrimes.

Since the internet and network started dominating our daily life, many things have changed, and so is the way people find and meet their soul mates [6]. They do not have to struggle to get acquainted by their dream woman or man any longer, just simply sitting comfortably in the corner of the room or café, solemnly staring at the phone screen or laptop, selecting a prospective spouse just by a click [7].

With the assistance of the present technology, online dating sites have been a common tool for individuals to find and meet new companions and potential mates [8]. Although online 
dating sites have the potential to bring great happiness into the lives of their customers, there is a cyber-risk as well: cybercriminals such as scammer abuse these services for their illegal benefit, causing victims heartbreak and financial damages [9].

The previous study related to the online dating scam, shows that the scam accounts detected on a popular online dating site over a period of eleven months and found that scammers commonly set up fake accounts on an online dating site, start interacting with a user on the site, and then lure her/him into sending them money, for example to pay for the flight needed to meet in person and they never show up after that, or to pay the nudity picture they sent that turned out to be someone else's nude picture [10]. The goal of scammers on online dating sites is very different from the one of legitimate users: while legitimate users want to get to know new people, and possibly start a romantic relationship, scammers seek vulnerable and gullible victims, with the purpose of extorting money from them [10].

Another type of cybercrime done by the cybercriminals in online dating site which included pornography content is "Sextortion". Sextortion is a serious crime that occurs when a perpetrator threatens to reveal intimate images of you online unless you give in to their demands. These demands are typically for money, further intimate images, or sexual favors. Perpetrators commonly target their victims through dating apps, social media, webcams or adult pornography sites. Typically, the perpetrator has or pretends to have some nudity images or videos of the victim. They threaten to publish them online or share them with friends, family members, or colleagues if the victim doesn't provide more material, engage in sexual acts, or hand over money [11]. To understand cybercrime and pornography that happened in the online dating site, the researcher has performed the analysis on an online dating site found in California and this website claimed to have 10 Million active members, 8 million female users, and 2 million male users, the users spread out in 139 countries, Including Indonesia.।

Based on the pre-research interview conducted on three DatingSites users in Indonesia, they experienced scams \& frauds that always started with the nude pictures as exchange into the financial transfer. The virtual world which connecting them has made the users lost their vision of telling which one is a real account which one is a fake account. Cybercrime and pornography content has become part of this DatingSites. Based on that phenomenon, the researcher wants to analyse to what extent Cybercrime and pornography developed in the DatingSite. The researcher is going to do a direct interview with 3 male users and 2 female users who are active members of the DatingSites. The aim of this research is to know how Cybercrime and pornography developed in virtual world. This study is expected to enrich knowledge in the communication science especially in media study about Cybercrime and Pornography.

\section{Method}

To analyzed how cybercrime and pornography developed on DatingSite, the researcher used the case study method by Robert K. Yin to explore and understand the phenomenon [12]. Case studies, in their true essence, explore and investigate contemporary real-life phenomenon through detailed contextual analysis of a limited number of events or conditions, and their relationships [13]. There are a number of advantages in using case studies. First, variations in terms of intrinsic, instrumental and collective approaches to case studies allow for both quantitative and qualitative analyses of the data, and second, the detailed qualitative accounts often produced in case studies not only help to explore or describe the data in real-life 
environment, but also help to explain the complexities of real life situations which may not be captured through experimental or survey research [14].

Methods used in case study to facilitate achieving the aim of constructing data most often include observations, interviews, focus groups, document, and artifact analysis [15]. In this research, interviews were conducted with five informants who has been an active member of DatingSite to provide information about the phenomenon of cybercrime and pornography that occurs on the website. The basis for selecting informants refers to criteria that are in line with research objectives, namely: the informants are members of one of the online DatingSites communities, where they are victims of cyber crime. This is known from the pre-research conducted by researchers. Interview is useful for getting the story behind the participant's experiences. The interviewer can pursue in-depth information around a topic and help the researcher to fulfill the research purposes.

\section{Results and Discussion}

After conducting interviews with 5 informants, researchers found 4 types of cybercrime and pornography that developed on DatingSites, namely:

1. Hacking: Account Stealing for sexual content \& sexual leisure purposes on the DatingSite.

Hacking is one of the most traditional forms of cybercrime and involves activities result in the compromise of computing systems and/or digital information. Hacking is the technique of finding the weak links or loopholes in the computer systems or the networks and exploiting it to gain unauthorized access to data or to change the features of the target computer systems or the networks [16].

Two of the male informants explained that their personal accounts on DatingSite were hacked by the hacker. It is causing material and non-material losses to both informants. Their account was taken over to commit other internet crime. The account belongs to the first informant was used to pursue the female users of the DatingSite to send their nudes pictures with the lure of money in return. While the account belongs to the second informant was used by the hacker for meeting the opposite sex through the DatingSite. DatingSite itself is not a free platform, to be the DatingSite member, the user has to pay the monthly subscription around \$30. Eventually, the two accounts returned to the original users.

After receiving their accounts back, informants were harmed by multiple inboxes on their DatingSite accounts that demanded money transfer. Based on their DatingSite's inbox history, it was turned out that the hacker of informant 1's account never sent money as promised to female users after receiving their nude pictures. While the informant 2 was harmed by the inboxes of several women who asked for payment after they (hacker \& female user) had sexual activity at the hotel.

The victims who were female users had no idea that informant 1 and informant 2's account had been hacked. It is because the hackers replaced the informant's profile pictures with some kind of a random cartoon image. They had no idea that they had sent their nude images to hackers and they also had no idea that men who engaged in sexual activity with them were hackers. Not the real owner of the DatingSite's account they had been talking to. The hacking case experienced by informant 1 and informant 2 was not reported to the police because the informants were embarrassed if the surrounding community found out that they are actually an active member of a DatingSite. 


\section{Doxxing on DatingSite.}

Doxxing is the practice of researching and publishing someone's personal information. The purpose of this practice is either to expose that person to legal prosecution, to embarrass the victim, to draw criticism towards that person, or to cause them physical harm. Doxxing is part of cybercrime in the form of identity-related crimes [17]. Many people's lives have been ruined by doxxing. Some doxxing attacks lead to public shaming. The effects can cause people to lose their jobs, their families, and their properties. Targets of major doxxing attacks have been forced into hiding and have had to delete all of their online accounts and change their identities [18].

Informant 3 (Female) became the victim of doxxing where her personal data was screenshotted by one of the male accounts she talked to on the DatingSite. The man took her details information and her profile picture to be distributed to his colleagues in the facebook with the aim of finding more information about Informant 3. Besides distributing informant 3's personal information, this man also attached a fake story stating that informant 3 is running his money. Personal information and fake news about the informant 3 had quickly spread out and eventually appear on one of Instagram's gossip account. With the availability of informants 3's personal information, Netizen are easily found her Instagram account and flocked to leave nasty comments on it. Informant 3 is now facing other types of cybercrime attack, namely hate crime. Hate crimes (and hate speech) are another form of online harassment that has made the transition to online. These are crimes that arise due to prejudice based on race, sexual orientation, gender, religion, ethnicity, disability, etc. Social media plays a central role in hate speech and crimes, particularly those that occur after significant events [17].

The clarification that has been done by her to clear up her name was useless. It did not have a significant impact because the negative rumors about her were way more viral than the clarifications she made on social media.

\section{Sextortion on the DatingSite}

Sexortation is forms of online harassment. Within the former, individuals, especially expartners, post sexual images of victims online without their permission. Criminals use these photo leaks to embarrass, humiliate, and demean victims. Sextortion is the gathering of sexual images or video and its use to blackmail individuals for further sexual footage or other favors.

Informant 4 is a female and she is a sextortion victim. Basically, Informant 4 met her boyfriend on dating site and she had been communicating with him online for 2 months. Her boyfriend claimed that he is from the Middle East and volunteering himself as a nurse while informant 4 is in Indonesia. Everything was going well and romantic until one day he started to ask her to send nude pics. At first she sent semi nudes but the noyfriend wanted more, so eventually Informant 4 sent two of her nude pics to her cyber boyfriend. One day, suddenly her boyfriend called her sobbing and crying telling her that his mom had been rushed to the hospital, the diagnosis was cancer. He was desperately trying to find a way to get money to pay his mom's medical bill. He asked her for $\$ 1000$ and promised her that he will return it as soon as he has the money. She refused and he tricked her into letting him add her on Facebook. But then she insisted to not send him the money. That's how she realized that she was dating a scammer and she blocked his contact and his social media and unmatch him on the DatingSite.Not so long after that, her nude pictures were already out there on the internet, and this ex-boyfriend she met on online dating site made another facebook account to send her link of her nude pictures as a proved that he did really spread her nude pictures because she doesn't send him the money. This case became serious when the company she worked for 
received her nude pictures and the nudity image of its victim will be permanently on the internet.

\section{Prostitution in Online DatingSite}

The Internet and computer technology have been developed and exploited by sex businesses to offer prostitution to men across the globe. The Internet has facilitated prostitution's shift from the street to indoor locations: to massage parlors, residential brothels, hotels [19].Online prostitution in Indonesia is not governed by the Criminal Code and the Electronic Information and Transaction [ITE] Law, However, there were a number of situations in which sex workers and consumers could be charged. If the sex workers were still underage, the customers could be slapped with articles from the Children Protection Law and sex workers who put sexually explicit pictures on social media could be charged using the Pornography Law, while pimps managing sex workers could be charged using existing regulations.

According to the informant 5, online prostitution is such a hype on the DatingSite. Many girls are offering their services by clearly putting their sexually explicit profile pictures and also describing on their DatingSite bio about how much money needed to spend a night with them. Informant 5 is one of the loyal customers in using female escort services. He had been meeting at least 8 female escorts from the DatingSite since early 2017 until the end of 2019. The service fee differs from one escort to another escorts, the rage is about IDR 500,000 to $5,000,000$ / night.

In doing their work, female escorts usually distribute nudity pictures to their customers as the references for how she might looking like in real life. The services they do is not only limited to sexual intercourse in real life, but they also provide phone sex and Sex cam (live porn show on webcam in real time).

\section{Conclusion}

Based on the findings, Cybercrime that occurs on dating sites and involves pornographic content includes sextortion, online prostitution and account hacking which is done with the aim of pursuing sexual satisfaction and making money. While cybercrime occurs without involving pornography content is doxxing. Doxxing that happened in this case was alleged to fulfill the doxxer's personal needs in terms of knowing more about the victim's personal information rather than financial gain. Those cybercrimes phenomenon had never been handled by the police because no one has ever reported it officially. The researcher believes that cybercrime and pornography phenomenon not only occurs on dating site but it spreads out widely on the cyber world such as social media, entertainment websites, etc. Cybercrime and pornography continue to increase along with the growing number of internet users and the increasing speed of internet connection, especially in Indonesia. Notwithstanding Indonesian cyber law has been regulated by the law No. 11/2008 regarding information and electronic transaction, but it has not been implemented effectively.

\section{Acknowledgments}

The authors would like to thank the Ministry of Education and Culture, Universitas Mercu Buana and Directorate Jenderal Higher Education (Dirjen. DIKTI) Jakarta Indonesia. 


\section{References}

[1] A. Mulyana, R. Briandana, and E. Rekarti, "ICT and Social Media as a Marketing Communication Platform in Facilitating Social Engagement in the Digital Era," Int. J. Innov. Creat. Chang., vol. 13, no. 5, pp. 1-16, 2020.

[2] D. Simmons, "The Dark Side of Technology - the evolution of cyber crime," pp. 1-3, 2012.

[3] R. Briandana, N. A. Dwityas, B. J. Priyono, and S. Audinna, "Film transformations from analog to digital: A case study of film restoration in Indonesia," Humanit. Soc. Sci. Rev., vol. 8, no. 1, pp. 78-84, 2020.

[4] M. C. Arcuri, M. Brogi, and G. Gandolfi, "Cyber Risk,” Identity Th., pp. 292-307, 2016.

[5] S. I. Astuti, L. Giri, and N. Hidayah, "Video Web Drama Series For Combating Disinformation," Aspiration J., vol. 1, no. 1, pp. 1-30, 2020.

[6] A. Jamil, E. Rekarti, R. Briandana, and S. Audinna, "The Role of Social Media Hashtags in Political Promotions : Mediating Role of Supply Chain Communication," Int. J. Supply Chain Manag., vol. 8, no. 6, pp. 181-188, 2019.

[7] R. Briandana and A. A. Azmawati, "New media audience and gender perspective : A reception analysis of millenials interpretation," Int. J. Humanit. Soc. Sci. Res., vol. 6, no. 1, pp. 58-63, 2020.

[8] P. Kirnandita, "Pelecehan Seksual Banyak Terjadi Sebelum Era Dating Online," Tirto.id, 2017.

[9] R. F. Marta et al., "Author compliance in following open journal system of communication science in Indonesia," in Journal of Physics: Conference Series, 2019, vol. 1175, no. 1, p. 12222 .

[10] J. Huang, G. Stringhini, and P. Yong, "Quit Playing Games With My Heart : Understanding Online Dating Scams," in International Conference on Detection of Instrutions and Malware, and Vulnerability Assessment, 2015, pp. 216-236.

[11] kari Paul, “'I was humiliated' — online dating scammers hold nude photos for ransom in 'sextortion' - MarketWatch.” 2019.

[12] R. K. Yin, “Applications of case study research,” Appl. Soc. Res. Methods Ser., 2013.

[13] S. Teegavarapu, J. D. Summers, and G. M. Mocko, "Case Study Method for Design Research: A Justification," no. May 2015, pp. 495-503, 2009.

[14] Zaidah Zainal, "Case study as a research method," J. Kemanus., 2017.

[15] H. Harrison, M. Birks, R. Franklin, and J. Mills, "Case Study Research: Foundations and Methods," Forum Qual. Soc. Res., vol. 18, no. 1, 2017.

[16] A. Gupta and A. Anand, "Ethical Hacking and Hacking Attacks," Int. J. Eng. Comput. Sci., no. May, 2017.

[17] J. R. C. Nurse, "Cybercrime and You : How Criminals Attack and the," 2018.

[18] S. Cooper, "What is Browser Fingerprinting and How to Avoid It." 2019.

[19] M. Farley, K. Franzblau, and M. A. Kennedy, "Online Prostitution and Trafficking.," Albany Law Rev., vol. 77, no. 3, pp. 1039-1094, 2014. 